\title{
VARIABILITY OF THE SPIN PERIOD OF THE WHITE DWARF IN THE INTERMEDIATE POLAR V405 AUR: LOW-MASS THIRD BODY OR PRECESSION?
}

\author{
V. V. Breus ${ }^{1}$, I. L. Andronov ${ }^{1}$, P. Dubovský ${ }^{2}$, S. V. Kolesnikov ${ }^{3}$, E. A. Zhuzhulina ${ }^{4}$, T. Hegedús ${ }^{5}$, P. Beringer ${ }^{5}$, \\ K. Petrík ${ }^{6}$, J. W. Robertson ${ }^{7}$, A. V. Ryabov ${ }^{3}$, I. Kudzej ${ }^{2}$, N. M. Shakhovskoy $^{8}$ \\ ${ }^{1}$ Department "High and Applied Mathematics", Odessa National Maritime University, Odessa, Ukraine, \\ e-mail:vitaly.breus@gmail.com,tt_ari@ukr.net \\ ${ }^{2}$ Vihorlat Astronomical Observatory, Humenne, Slovakia \\ ${ }^{3}$ Astronomical Observatory, Odessa National University, Odessa, Ukraine \\ ${ }^{4}$ Department of Astronomy, Odessa National University, Odessa, Ukraine \\ ${ }^{5}$ Baja Astronomical Observatory, Baja, Hungary \\ ${ }^{6}$ Astronomical Observatory, Hlohovec, Slovakia \\ ${ }^{7}$ Arkansas Tech University, Russellville, USA \\ ${ }^{8}$ Crimean Astrophysical Observatory, Nauchny, Ukraine
}

(Received June 10, 2013)

\begin{abstract}
We present the results of photometric CCD observations of the magnetic cataclysmic variable V405 Aurigae (RX J0558.0+5353 = 1RXS J055800.7+535358) obtained using different instruments. We analysed variability of the spin period of the white dwarf in the V405 Aur (RX J0558.0+5353) system using our observations and previously published maxima timings. The spin period of the system in 2010-2012 is $P=545.4558163(94)$ s. As we have gaps in observational data, we present 2 hypotheses of the spin period variability of this system - a cubic ephemeris which may be interpreted by a precession of the magnetic white dwarf or a periodic change with a period of 6.2 years and semi-amplitude of $17.2 \pm 1.8 \mathrm{sec}$. The periodic variations may be interpreted by a lighttime effect caused by a low-mass star $\left(M_{3} \geq 0.09 M_{\odot}\right)$. In this case, the system belongs to a rare class of cataclysmic variables with a third body.
\end{abstract}

Key words: binary stars, close systems, accretion disks, novae, V405 Aurigae.

PACS number(s): 97.10.Gz, 97.10.Kc, 97.10.Ld, 97.30.Qt, 97.80.Gm, 97.82.Cp, 98.35.Mp

\section{INTRODUCTION}

The intermediate polar V405 Aur was discovered as an optical counterpart of the ROSAT soft X-ray source 1RXS J055800.7+535358 (RX J0558.0+5353) by Haberl et al. [1]. The soft X-ray flux was changing with a period of $272.74 \mathrm{~s}$, which was supposed to be a spin period of the white dwarf. The presence of optical pulsations at a period of $272.785 \pm 0.003 \mathrm{~s}$ was reported by Ashoka et al. [2].

Later Allan et al. [3] and Skillman [4] made independent announcements that the spin period of the white dwarf is twice that previously suggested (545.45s). The double value of the spin period was justified by detection of circular polarization with a period of $P=$ $0.006301 \pm 0.000055 \mathrm{~d}(544.4 \pm 4.8) \mathrm{s}$ and semi-amplitude of $1.80 \pm 0.16$ percent (Shakhovskoj and Kolesnikov [5]). Noting very similar photometric maxima (two during a polarimetric period), Shakhovskoj et al. [6] suggested a nearly-equatorial location of two accretion columns.

Evans and Hellier [7] discussed the double-peaked spin pulse. The shape of the phase curve is wavelengthdependent, with a strong separation between the peaks at soft X-ray range and a "saw-tooth" shape at hard Xrays. This is naturally explained by an inequality of the columns.

Piirola et al. [8] analysed the maxima timings obtained in 1994-2007 and published second-order polynomial fit to the timings:

$$
\begin{aligned}
T_{\max } & =H J D 2449681.46389(5)+0.0063131474(4) E \\
& +4(4) \cdot 10^{-16} E^{2} .
\end{aligned}
$$

The quadratic term is formally positive (corresponding to a period increase). However, this term deviates from zero by $1 \sigma$, so is not statistically significant. Given in brackets is a statistical error estimate in the units of a last digit.

\section{OBSERVATIONS}

We obtained photometric CCD observations using different telescopes: $1 \mathrm{~m}$ VNT (filters V and R) and $28 \mathrm{~cm}$ Pupava (unfiltered) reflectors in Vihorlat Astronomical Observatory, Humenné, Slovakia, $35 \mathrm{~cm}$ BAT and $50 \mathrm{~cm}$ reflector in Baja Astronomical Observatory, Hungary (V and R filters) and 20cm MEADE LX-200 at the Observatory and Planetarium in Hlohovec, Slovakia (V and $R$ filters). Also we used UBVRI photometry obtained at the $1.25 \mathrm{~m} \mathrm{AZT-11}$ and wide-R photometry at the $2.6 \mathrm{~m}$ Shain Telescope at the Crimean Astrophysical Observatory, Nauchny, Ukraine and unfiltered observations from the Arkansas Tech University Observatory. The journal of observations is presented in Table 1 . 


\begin{tabular}{|c|c|c|}
\hline UT date & HJD start & Telescope \\
\hline$\overline{04.10 .1997}$ & $50726.48273 \quad 0^{\mathrm{h}} 44^{\mathrm{m}}$ & ZTSh \\
\hline 02.11.1997 & $50755.577971^{\mathrm{h}} 12^{\mathrm{m}}$ & AZT11 \\
\hline 06.11 .1997 & $50759.556971^{\mathrm{h}} 45^{\mathrm{m}}$ & AZT11 \\
\hline 01.02 .1998 & $50846.306560^{\mathrm{h}} 19^{\mathrm{m}}$ & ZTSh \\
\hline 24.09.1998 & $51081.413352^{\mathrm{h}} 46^{\mathrm{m}}$ & AZT11 \\
\hline 16.12 .1998 & $51164.340684^{\mathrm{h}} 42^{\mathrm{m}}$ & ZTSh \\
\hline 18.12.1998 & $51166.419454^{\mathrm{h}} 00^{\mathrm{m}}$ & ZTSh \\
\hline 19.12.1998 & $51167.401822^{\mathrm{h}} 28^{\mathrm{m}}$ & AZT11 \\
\hline 12.02 .1999 & $51222.192973^{\mathrm{h}} 30^{\mathrm{m}}$ & AZT11 \\
\hline 17.03.1999 & $51255.253331^{\mathrm{h}} 43^{\mathrm{m}}$ & ZTSh \\
\hline 09.11.1999 & $51492.502221^{\mathrm{h}} 29^{\mathrm{m}}$ & ZTSh \\
\hline 10.11.1999 & $51493.529052^{\mathrm{h}} 05^{\mathrm{m}}$ & AZT11 \\
\hline 08.03 .2000 & $51612.251292^{\mathrm{h}} 02^{\mathrm{m}}$ & ZTSh \\
\hline 01.10 .2000 & $51819.422424^{\mathrm{h}} 03^{\mathrm{m}}$ & ZTSh \\
\hline 16.09.2001 & $52169.439193^{\mathrm{h}} 07^{\mathrm{m}}$ & ZTSh \\
\hline 18.09.2001 & $52171.46197 \quad 0^{\mathrm{h}} 36^{\mathrm{m}}$ & ZTSh \\
\hline 13.10 .2001 & $52196.491042^{\mathrm{h}} 01^{\mathrm{m}}$ & ZTSh \\
\hline 16.10 .2001 & $52199.440782^{\mathrm{h}} 06^{\mathrm{m}}$ & ZTSh \\
\hline 17.10.2001 & $52200.549551^{\mathrm{h}} 33^{\mathrm{m}}$ & ZTSh \\
\hline 03.10 .2002 & $52551.593332^{\mathrm{h}} 46^{\mathrm{m}}$ & ZTSh \\
\hline 21.11.2003 & $52965.630021^{\mathrm{h}} 47^{\mathrm{m}}$ & ZTSh \\
\hline 15.09.2004 & $53264.624651^{\mathrm{h}} 57^{\mathrm{m}}$ & ZTSh \\
\hline 16.09.2004 & $53265.587092^{\mathrm{h}} 40^{\mathrm{m}}$ & ZTSh \\
\hline 01.10 .2005 & $53645.593622^{\mathrm{h}} 54^{\mathrm{m}}$ & ZTSh \\
\hline 01.10 .2005 & $53645.650301^{\mathrm{h}} 43^{\mathrm{m}}$ & ZTSh \\
\hline 30.11 .2005 & $53705.401242^{\mathrm{h}} 31^{\mathrm{m}}$ & ZTSh \\
\hline 24.10 .2006 & $54033.583602^{\mathrm{h}} 04^{\mathrm{m}}$ & ZTSh \\
\hline 14.02 .2007 & $54146.346642^{\mathrm{h}} 01^{\mathrm{m}}$ & ZTSh \\
\hline 18.02.2007 & $54150.316284^{\mathrm{h}} 03^{\mathrm{m}}$ & ZTSh \\
\hline 10.01.2008 & $54476.349923^{\mathrm{h}} 23^{\mathrm{m}}$ & ZTSh \\
\hline 10.02 .2008 & $54507.298413^{\mathrm{h}} 13^{\mathrm{m}}$ & ZTSh \\
\hline 08.03.2008 & $54534.236003^{\mathrm{h}} 11^{\mathrm{m}}$ & ZTSh \\
\hline 28.12 .2008 & $54829.321440^{\mathrm{h}} 10^{\mathrm{m}}$ & ZTSh \\
\hline 16.01 .2009 & $54848.5500810^{\mathrm{h}} 43^{\mathrm{m}}$ & SCT 8-in \\
\hline 17.01.2009 & $54849.647786^{\mathrm{h}} 34^{\mathrm{m}}$ & SCT 8-in \\
\hline 20.01.2009 & $54852.694285^{\mathrm{h}} 57^{\mathrm{m}}$ & SCT 8-in \\
\hline 21.01.2009 & $54853.545317^{\mathrm{h}} 24^{\mathrm{m}}$ & SCT 8-in \\
\hline 22.01.2009 & $54854.54545 \quad 6^{\mathrm{h}} 29^{\mathrm{m}}$ & SCT 8-in \\
\hline 24.01.2009 & $54856.565114^{\mathrm{h}} 44^{\mathrm{m}}$ & SCT 8-in \\
\hline 02.02 .2009 & $54865.656162^{\mathrm{h}} 54^{\mathrm{m}}$ & SCT 8-in \\
\hline 04.02 .2009 & $54867.646527^{\mathrm{h}} 40^{\mathrm{m}}$ & SCT 8-in \\
\hline 16.02 .2009 & $54879.568593^{\mathrm{h}} 33^{\mathrm{m}}$ & SCT 8-in \\
\hline 18.02 .2009 & $54881.556067^{\mathrm{h}} 27^{\mathrm{m}}$ & SCT 8-in \\
\hline 19.02.2009 & $54882.602708^{\mathrm{h}} 17^{\mathrm{m}}$ & SCT 8-in \\
\hline 20.02.2009 & $54883.583677^{\mathrm{h}} 02^{\mathrm{m}}$ & SCT 8-in \\
\hline 21.02.2009 & $54884.59240 \quad 6^{\mathrm{h}} 46^{\mathrm{m}}$ & SCT 8-in \\
\hline 01.03.2009 & $54892.695114^{\mathrm{h}} 34^{\mathrm{m}}$ & SCT 8-in \\
\hline 19.08.2009 & $55062.538302^{\mathrm{h}} 00^{\mathrm{m}}$ & $50 \mathrm{~cm}$ \\
\hline 29.08.2009 & $55072.554851^{\mathrm{h}} 50^{\mathrm{m}}$ & $50 \mathrm{~cm}$ \\
\hline 24.09.2009 & $55098.520061^{\mathrm{h}} 45^{\mathrm{m}}$ & Meade \\
\hline 26.11.2009 & $55162.5539711^{\mathrm{h}} 05^{\mathrm{m}}$ & SCT 10-in \\
\hline 27.11.2009 & $55163.616249^{\mathrm{h}} 34^{\mathrm{m}}$ & SCT 8-in \\
\hline 28.11.2009 & $55164.691993^{\mathrm{h}} 11^{\mathrm{m}}$ & SCT 8-in \\
\hline 30.11 .2009 & $55166.682658^{\mathrm{h}} 10^{\mathrm{m}}$ & SCT 8-in \\
\hline 28.12 .2009 & $55194.603639^{\mathrm{h}} 33^{\mathrm{m}}$ & SCT 10-in \\
\hline
\end{tabular}

Table 1. Journal of observations.

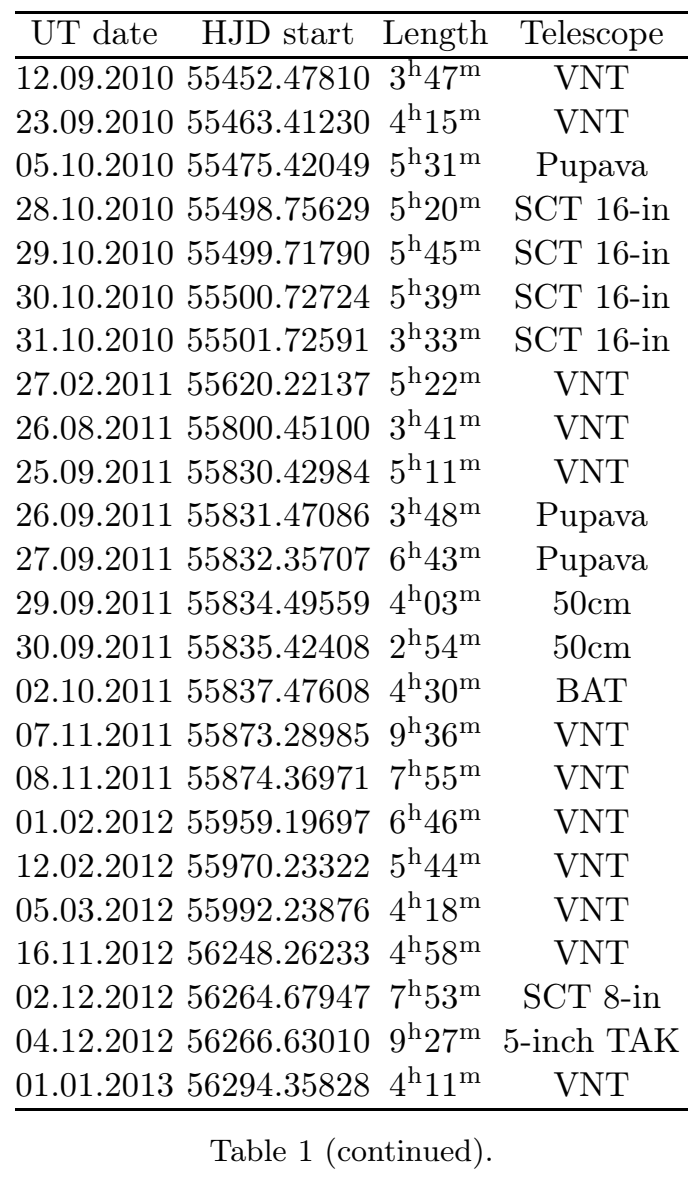

The photometric data were reduced using the CMunipack software package. The final time series were obtained using the program MCV (I. L. Andronov, A. V. Baklanov [9]) taking into account multiple comparison stars. The periodogram analysis was carried out using MCV and FDCN (Andronov [10]).

\section{DETERMINATION OF MAXIMA TIMINGS}

For phase curves, we have used a preliminary value of the spin period of $P=0{ }^{\mathrm{d}} 0063131474$ and initial epoch 2449681.46389 (Eq. (1) of Piirola et al. [8]). The phase curves for V, Rc observations are shown in Figs. 1 and 2. They exhibit a clear double-hump structure. Using this value of the spin period, we have used a second-order trigonometric polynomial fit to the magnitudes

$$
\begin{aligned}
m(t) & =C_{1}+C_{2} \cos (\omega t)+C_{3} \sin (\omega t) \\
& +C_{4} \cos (2 \omega t)+C_{5} \sin (2 \omega t)
\end{aligned}
$$

where $\omega=2 \pi / P$, and $P$ is period. The coefficients $C_{3}$, $C_{5}$ describe differences between the two humps. However, the last two terms correspond to a "mean" shape of the pulse from two similar maxima. Thus, as the moment of maximum, we have used the moment of maximum $T_{02}$ of the first harmonic of the fit, i. e.

$$
\begin{aligned}
m_{2}(t) & =C_{4} \cos (2 \omega t)+C_{5} \sin (2 \omega t) \\
& =-R_{2} \cos \left(2 \omega\left(t-T_{02}\right)\right) .
\end{aligned}
$$




\begin{tabular}{|c|c|c|c|c|c|c|c|c|}
\hline HJD-2400000 & \pm & Rem & HJD-2400000 & \pm & Rem & HJD-2400000 & \pm & Rem \\
\hline 50726.49510 & 0.00003 & 7 & 53645.65783 & 0.00001 & 7 & 54854.67785 & 0.00005 & 8 \\
\hline 50755.60137 & 0.00013 & 6 & 53645.68671 & 0.00001 & 7 & 54856.66673 & 0.00008 & 8 \\
\hline 50755.60140 & 0.00008 & 6 & 53705.45918 & 0.00007 & 7 & 54865.71649 & 0.00012 & 8 \\
\hline 50755.60141 & 0.00006 & 6 & 54033.61713 & 0.00001 & 7 & 54867.80612 & 0.00008 & 8 \\
\hline 50755.60146 & 0.00011 & 6 & 54146.36630 & 0.00004 & 7 & 54879.64257 & 0.00009 & 8 \\
\hline 50755.60155 & 0.00010 & 6 & 54150.40657 & 0.00001 & 7 & 54881.70701 & 0.00011 & 8 \\
\hline 50759.59442 & 0.00014 & 6 & 54387.66949 & 0.00027 & 2 & 54882.77077 & 0.00007 & 8 \\
\hline 50759.59445 & 0.00014 & 6 & 54388.68261 & 0.00017 & 2 & 54883.73345 & 0.00008 & 8 \\
\hline 50759.59446 & 0.00008 & 6 & 54389.68600 & 0.00011 & 2 & 54884.73404 & 0.00005 & 8 \\
\hline 50759.59452 & 0.00007 & 6 & 54392.67580 & 0.00015 & 2 & 54892.78944 & 0.00006 & 8 \\
\hline 50759.59456 & 0.00006 & 6 & 54393.57216 & 0.00008 & 2 & 55162.78212 & 0.00003 & 8 \\
\hline 50846.31466 & 0.00003 & 7 & 54393.67628 & 0.00014 & 2 & 55163.82428 & 0.00006 & 8 \\
\hline 51081.47661 & 0.00004 & 6 & 54394.67363 & 0.00027 & 2 & 55164.75561 & 0.00013 & 8 \\
\hline 51081.47664 & 0.00011 & 6 & 54395.71194 & 0.00051 & 2 & 55166.85407 & 0.00005 & 8 \\
\hline 51081.47666 & 0.00005 & 6 & 54396.66273 & 0.00044 & 2 & 55194.80822 & 0.00004 & 8 \\
\hline 51081.47674 & 0.00008 & 6 & 54397.67291 & 0.00031 & 2 & 55452.55800 & 0.00005 & 3 \\
\hline 51081.47675 & 0.00007 & 6 & 54398.64800 & 0.00021 & 2 & 55452.55802 & 0.00005 & 3 \\
\hline 51164.44289 & 0.00001 & 7 & 54405.68025 & 0.00022 & 2 & 55463.50182 & 0.00007 & 3 \\
\hline 51166.50196 & 0.00001 & 7 & 54406.66561 & 0.00013 & 2 & 55463.50185 & 0.00006 & 3 \\
\hline 51167.45234 & 0.00005 & 6 & 54407.64707 & 0.00013 & 2 & 55475.53543 & 0.00009 & 3 \\
\hline 51167.45235 & 0.00003 & 6 & 54407.80797 & 0.00008 & 2 & 55498.86627 & 0.00005 & 8 \\
\hline 51167.45235 & 0.00005 & 6 & 54409.65134 & 0.00017 & 2 & 55499.89877 & 0.00004 & 8 \\
\hline 51167.45236 & 0.00003 & 6 & 54410.66438 & 0.00032 & 2 & 55500.84520 & 0.00003 & 8 \\
\hline 51167.45244 & 0.00005 & 6 & 54416.12864 & 0.00014 & 2 & 55501.79233 & 0.00005 & 8 \\
\hline 51222.26302 & 0.00006 & 6 & 54418.64771 & 0.00035 & 2 & 55620.33304 & 0.00002 & 3 \\
\hline 51222.26302 & 0.00007 & 6 & 54419.64116 & 0.00026 & 2 & 55709.59139 & 0.00004 & 3 \\
\hline 51222.26304 & 0.00009 & 6 & 54420.63655 & 0.00065 & 2 & 55800.52914 & 0.00007 & 3 \\
\hline 51222.26305 & 0.00006 & 6 & 54421.45335 & 0.00028 & 2 & 55830.53866 & 0.00004 & 3 \\
\hline 51222.26309 & 0.00007 & 6 & 54421.52664 & 0.00036 & 2 & 55831.54871 & 0.00007 & 3 \\
\hline 51255.30291 & 0.00003 & 7 & 54427.61780 & 0.00031 & 2 & 55832.49582 & 0.00005 & 3 \\
\hline 51492.53186 & 0.00011 & 7 & 54436.61510 & 0.00019 & 2 & 55834.57600 & 0.00009 & 4 \\
\hline 51493.57691 & 0.00005 & 6 & 54437.55549 & 0.00021 & 2 & 55834.57911 & 0.00007 & 4 \\
\hline 51493.57696 & 0.00006 & 6 & 54438.09861 & 0.00009 & 2 & 55835.48504 & 0.00010 & 4 \\
\hline 51493.57699 & 0.00004 & 6 & 54438.60984 & 0.00011 & 2 & 55835.48834 & 0.00012 & 4 \\
\hline 51493.57701 & 0.00004 & 6 & 54439.54781 & 0.00031 & 2 & 55837.58100 & 0.00008 & 5 \\
\hline 51520.27194 & 0.00020 & 1 & 54447.46696 & 0.00061 & 2 & 55837.58102 & 0.00013 & 5 \\
\hline 51612.29875 & 0.00001 & 7 & 54447.63452 & 0.00036 & 2 & 55873.49012 & 0.00002 & 3 \\
\hline 51819.50939 & 0.00001 & 7 & 54476.41950 & 0.00003 & 7 & 55874.53493 & 0.00003 & 3 \\
\hline 52169.50700 & 0.00001 & 7 & 54507.36966 & 0.00003 & 7 & 55909.37092 & 0.00002 & 3 \\
\hline 52171.47328 & 0.00003 & 7 & 54520.40288 & 0.00013 & 2 & 55959.33950 & 0.00003 & 3 \\
\hline 52196.53034 & 0.00002 & 7 & 54534.30477 & 0.00001 & 7 & 55970.35274 & 0.00004 & 3 \\
\hline 52199.45302 & 0.00004 & 7 & 54543.38921 & 0.00016 & 2 & 55992.32885 & 0.00003 & 3 \\
\hline 52200.57680 & 0.00002 & 7 & 54829.33040 & 0.00004 & 7 & 56248.36480 & 0.00004 & 3 \\
\hline 52551.65589 & 0.00002 & 7 & 54848.77188 & 0.00005 & 8 & 56264.83003 & 0.00006 & 8 \\
\hline 52965.67156 & 0.00002 & 7 & 54849.80093 & 0.00005 & 8 & 56266.81543 & 0.00005 & 8 \\
\hline 53264.66256 & 0.00001 & 7 & 54852.82184 & 0.00005 & 8 & 56294.44126 & 0.00004 & 3 \\
\hline 53265.64182 & 0.00001 & 7 & 54853.68357 & 0.00008 & 8 & & & \\
\hline
\end{tabular}

Table 2. Spin maxima timings for V405 Aur.

Remarks:

(1) Data from NSVS.

(2) Data from SuperWASP.

(3) Observations at Kolonica Observatory.

(4) VR photometry at $50 \mathrm{~cm}$.

(5) VR photometry at the Beringer Automated Telescope (BAT).

(6) UBVRI photometry at AZT-11.

(7) WR (wide R) photometry at the $2.6 \mathrm{~m}$ Shain Telescope.

(8) Photometry by Jeff Robertson. 


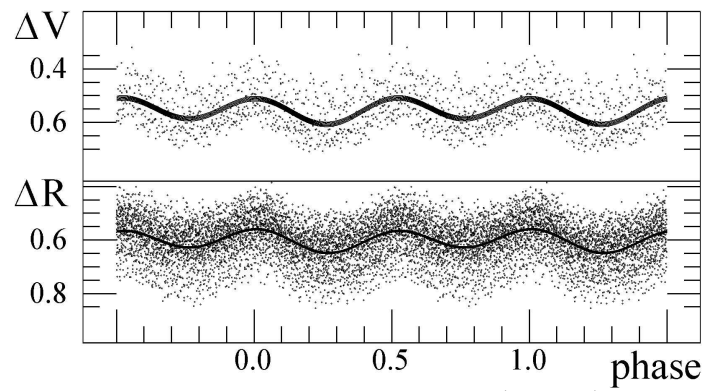

Fig. 1. Phase curve of the V405 Aur (circles) with a 2-nd order trigonometric polynomial approximation and " $\pm 1 \sigma$ ", " $\pm 2 \sigma$ " error corridors.

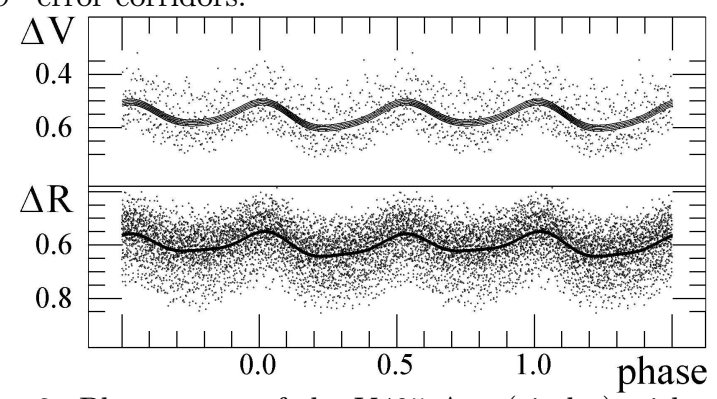

Fig. 2. Phase curve of the V405 Aur (circles) with a 4-th order trigonometric polynomial approximation and " $\pm 1 \sigma$ ", " $\pm 2 \sigma$ " error corridors.

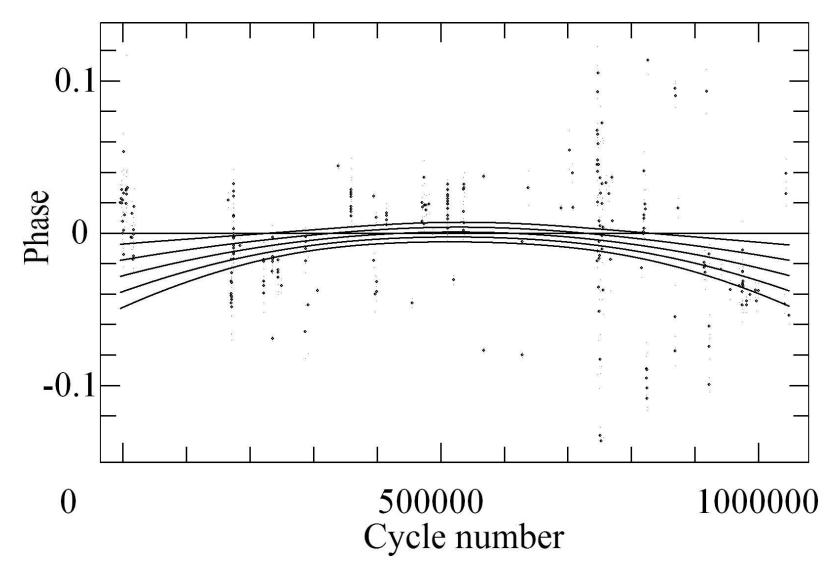

Fig. 3. Dependence of phases of maxima timings on cycle number of the spin period: circles - original observations, line - an approximation using 2-nd order polynomial fit with corresponding $\pm 1 \sigma$ and $\pm 2 \sigma$ error corridors.

The minus sign before the value of semi-amplitude corresponds to a maximum of flux (i.e. the minimum of the brightness in stellar magnitudes). Obviously, in this method, the maximum of another pulse is shifted exactly by a value of $P / 2$. We preferred to use this parameter instead of individual maxima, which are determined with much worse accuracy.

Resulting "mean maxima timings" are listed in Table 2. In an addition to our own time series, we have used the SuperWASP public archive [11]. Initially, we have split these data into nightly runs. But, as the further analysis have shown, the scatter of phases is much larger than for our own data. Thus, for better statistics, we have merged the SuperWASP data into 6 intervals, and only timings with good accuracy were taken into account. Although, two moments (HJD 2455709.59139 and 2455909.37092) are also "seasonal", corresponding not to a single night, but to all observational runs obtained in Kolonica in $\mathrm{V}$ and $\mathrm{R}$, respectively.

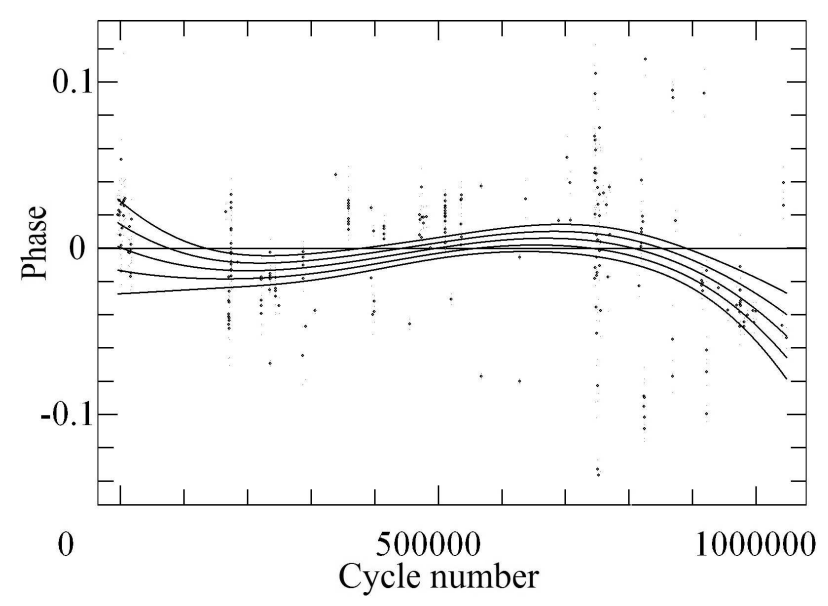

Fig. 4. Dependence of phases of maxima timings on cycle number of the spin period: circles - original observations, line - an approximation using 3rd order polynomial fit with corresponding $\pm 1 \sigma$ and $\pm 2 \sigma$ error corridors.

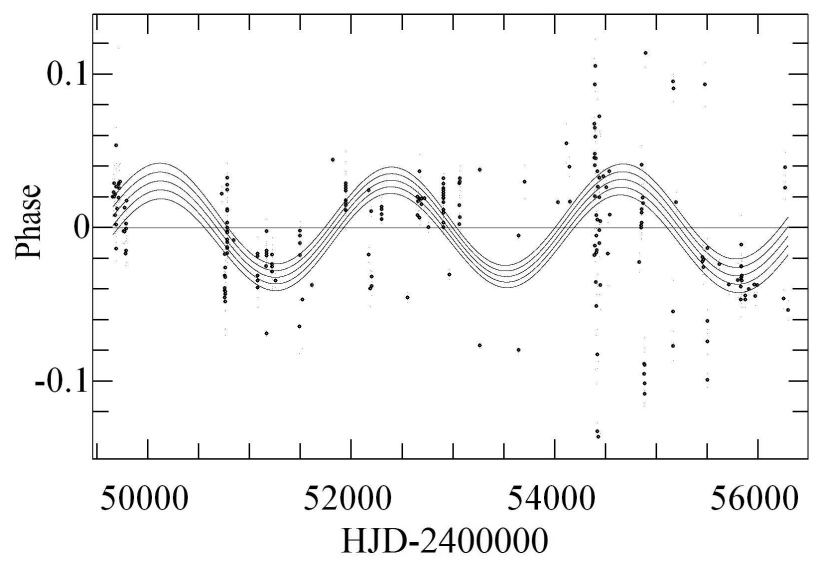

Fig. 5. Dependence of phases of maxima timings on HJD: circles - original observations, line - an approximation using 1-st order trigonometric and algebraic polynomial fits with corresponding $\pm 1 \sigma$ and $\pm 2 \sigma$ error corridors.

It should be noted that unfortunately not all the authors published accuracy estimates of the timings. Thus we had to assign formal accuracy to their data. E.g. for the data published by Skillman [4] we assigned the value of $\sigma_{\phi}=0.0118$, which was estimated as a standard error of phases from his list. For all other initial epochs published without error estimate we assigned a formal value of $\sigma_{\phi}=0.02$

\section{"O-C" ANALYSIS}

The $\mathrm{O}-\mathrm{C}$ diagram for historical timings compiled by Piirola et al. [8], maxima timings published in $[2,4,7]$ and our own ones listed in the Table 2 is shown in Fig. 3-5. Contrary to a classical representation of the " $\mathrm{O}-\mathrm{C}$ diagram" as a dependence of the timings from an ephemeris, 
i. e.

$$
\mathrm{O}-\mathrm{C}=T-\left(T_{0}+P \cdot E\right)
$$

on the cycle number $E$, we have used phases instead, i. e. $\phi=(\mathrm{O}-\mathrm{C}) / P$. For a correct ephemeris, the phases should be concentrated near the zero value. In our case, the times of maxima estimated by a program correspond to a harmonic with a double frequency, thus it is expected that phases like $-0.5,+0.5$ correspond to the same "zero", and thus one may make corrections for these values. For a complete set of "our+published" data, the phases seem to range from -0.13 to 0.11 .

Contrary to a suggestion of Piirola et al. [8], the points for the recent years show a distinct period decrease.

The simplest hypothesis is that the period has undergone change (approximately in $2007(E \approx 713491))$. We analysed separately photometric data, obtained at Vihorlat Astronomical Observatory in 2010-2013. As light curves in $\mathrm{V}$ and $\mathrm{R}$ filters had comparable amplitudes but different stellar magnitudes, so we subtracted the mean value of stellar magnitude from the data in each filter and joined it. We determined the new value of period and initial epoch that better corresponds all spin maxima timings in our observations.

$$
\begin{aligned}
T_{\max } & =\text { HJD } 2455882.470614(25) \\
& +0.00631314602(46) \cdot E .
\end{aligned}
$$

However, previous studies of intermediate polars argue for smooth period variations rather than period jumps, so we analysed other models for the period variations.

To decrease the error estimate of the initial epoch and the period, we computed the ephemeris for a different integer epoch $E_{0}$, which is close to a sample mean of the observational values. In our case, $E_{0}=504600$. A weighted fit to the phases of maxima $\phi$ (which are related to the traditional values of $(\mathrm{O}-\mathrm{C})=\phi P)$ leads to the following quadratic ephemeris:

$$
\begin{aligned}
T_{\max } & =H J D 2452867.07807(2) \\
& +0.006313147426(70) \cdot\left(E-E_{0}\right) \\
& -659(233) \cdot 10^{-18}\left(E-E_{0}\right)^{2} .
\end{aligned}
$$

The value of the quadratic term $Q$ reaches $2.8 \sigma$, so its deviation from zero is not statistically significant. It does not fit our recent observations enough good (see Fig. 3), so we calculated the 3rd order weighted fit to the phases of maxima and got the following cubic ephemeris

$$
\begin{aligned}
T_{\max } & =H J D 2452867.07807(2) \\
& +0.006313147760(131) \cdot\left(E-E_{0}\right) \\
& -502(237) \cdot 10^{-18}\left(E-E_{0}\right)^{2} \\
& -239(80) \cdot 10^{-23}\left(E-E_{0}\right)^{3} .
\end{aligned}
$$

It corresponds to all observations better (see Fig. 4) and fits most recent observations showing a distinct negative trend.

Also we checked a hypothesis of periodic change of $\mathrm{O}-\mathrm{C}$. We calculated the periodogram using the approx- imation combining a 1-st order trigonometric and a 1st order algebraic polynomials (see Fig. 5). The maximum peak at the periodogram corresponds to a period of $2268^{\mathrm{d}}=6.2 \mathrm{yr}$. The corresponding fit is

$$
\begin{aligned}
\phi & =-0.00049(219)+0.0000002(14) \cdot(T-2452881) \\
& +0.0315(32) \cos (2 \pi \cdot(T-2452389) / 2268) .
\end{aligned}
$$

As these periodic variations are statistically significant (at a level of semi-amplitude of $9.7 \sigma$ ), one may suggest a third body orbiting the inner binary system with a period of $\approx 6.2 \mathrm{yr}$, with a distance of the center of masses to the binary of $17.2 \pm 1.8$ light seconds, or $(5.15 \pm 0.53) \cdot 10^{9}$ meters $)$. The corresponding mass function [12] is $F(M) \approx 0.09 M_{\odot}$, so a third body may be a low-mass red dwarf.

\section{COLOR INDICES VS. STATISTICALLY OPTIMAL FIT}

Using the software FDCN [10] and the observations obtained in Kolonica, we determined that statistically optimal number of harmonics is 4 . The phase 0 corresponds to a maximum preceding the primary (deeper) minimum, similarly to the definition of other authors (e.g. [3]). The best fit is shown in Fig. 2 for two filters $\mathrm{V}$ and $\mathrm{R}$. To analyse variations of the color index in the instrumental system, for each phase we computed V-R and the corresponding error estimate

$$
\sigma_{V-R}=\left(\sigma_{V}^{2}+\sigma_{R}^{2}\right)^{1 / 2} .
$$

The corresponding phase light curve is shown in Fig. 6. It seems to be slightly asymmetric, with a maximum occurring slightly earlier than zero. The statistical error of the 4 th order trigonometric polynomial is much larger than for the upper curve, so the asymmetries in the shape are not statistically significant. For separate nights, the error estimates are even larger. So finally we used a secondorder trigonometric polynomial. Although the color indexes are nearly the same at phases of minima, the excess of the color index is twice larger at phase $\phi=0.5$ than at phase $\phi=0.0$. This is an interesting observational fact, which could be used for future modelling. A more detailed analysis of the curves of brightness and color index will be published elsewhere.

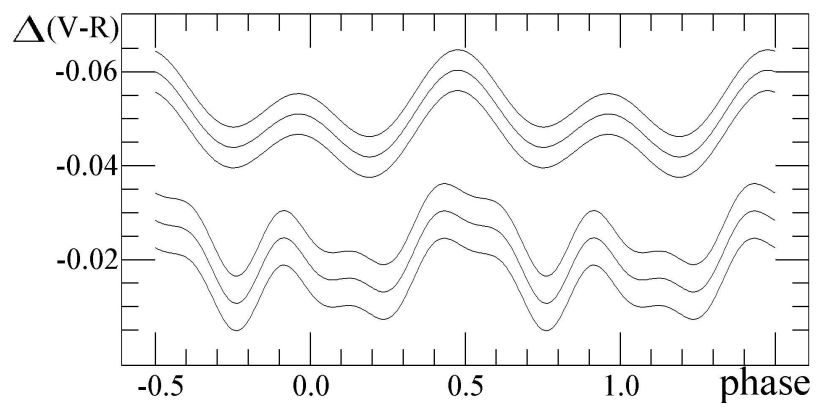

Fig. 6. The color index $\mathrm{V}-\mathrm{R}$ phase curve for approximations using trigonometric polynomials of order 2 (upper, shifted by $0 .^{\mathrm{m}} 03$ ) and 4 (bottom) and corresponding " $\pm 1 \sigma$ " corridor. 


\section{DISCUSSION AND CONCLUSIONS}

Period variations are frequently observed in intermediate polars and are typically detectable at a time scale of decades. Some objects do not show a statistically significant period change (e.g.1RXS J180340.0 + 401214 = RXJ $1803=$ V1323 Her [13], some show a period decrease (e.g. BG CMi [14], EX Hya [15,16]), some show a period increase, but some show increase and decrease during a couple decades of observations (e.g. FO Aqr [17]).

From theoretical expectations, the spin periods of the white dwarf should be equal to some equilibrium value, which is equal to the period of "Kepler" rotation of the inner accretion disk at a distance of the magnetospheric radius $[18,19]$. Period variations may be caused by changes of the accretion rate due to modulation of the mass transfer caused by magnetic activity of the red secondary [20,21] fluctuations of the orbital separation [23], or precession of the magnetic white dwarf (which will be present either with constant, or variable accretion rate) [22]. For another object FS Aur in the same constellation, Tovmassian et al. $[25,26]$ suggested precession of the magnetic white dwarf.

At time scales of decades, one may see only a part of the curve of cyclic variations. Thus apparently the "O-C" diagram may be not a "wave", but a square (for smaller time intervals) or cubic parabola (for larger intervals).

An alternate model is the presence of a third body - a star or a massive planet. In this case, the theoretical "O-C" diagram is a periodic wave ("mono-harmonic" for circular orbit or "multi-harmonic"for elliptic orbit), which generally is superimposed onto a trend (cf. [24]). Our analysis using the "MCV" software [9] shows that the harmonics are not statistically significant, so, assuming a circular orbit with a period of $6.2 \mathrm{yr}$, we obtained the value of the mass function of $f\left(M_{3}\right)=0.09 M_{\odot}$. As this is a lower limit of the mass of the third body, we may suggest that this is not a planet, but probably a red dwarf.

Contrary to the third-order polynomial, the sinusoidal fit shows a return to zero of phases at the end of the interval of observations. This difference will increase in future. Thus there may be a check-out, which model is correct, during even a year or two of subsequent observations.

Acknowledgements. This paper is a part of the National project "Ukrainian Virtual Observatory" [27] and international project "Inter-Longitude Astronomy" [28].
[1] F. Haberl et al., Astron. Astrophys. 291, 171 (1994).

[2] B. N. Ashoka, T. M. K. Marar, S. Seetha, K. Kasturirangan, J. C. Bhattacharyya, Astron. Astrophys. 297, L83 (1995).

[3] A. Allan, K. Horne, R. W. Hilditch, Int. Astron. Union Circ. 6154, 2 (1995).

[4] D. R. Skillman, Publ. Astron. Soc. Pacif. 108, 130 (1996).

[5] N. M. Shakhovskoj, S. V. Kolesnikov, Int. Astron. Union Circ. 6760, 2 (1997).

[6] N. M. Shakhovskoy, I. L. Andronov, S. V. Kolesnikov, Astron. Gesellschaft Abs. Ser. 18, 16 (2001).

[7] P. A. Evans, C. Hellier, Mon. Not. Roy. Astron. Soc. 353, 447, (2004).

[8] V. Piirola, N. Vornanen, A. Berdyugin, S. J. Coyne, Astrophys. J. 684, 558 (2008).

[9] I. L. Andronov, A. V. Baklanov, Astron. School Rep. 5, 264 (2004) [http://uavso.pochta.ru/mcv].

[10] I. L. Andronov, Odessa Astron. Publ. 7, 49 (1994).

[11] O. W. Butters, R. G. West, D. R. Anderson, et al., Astron. Astrophys. 520, 4 (2010).

[12] K. R. Lang, Astrophysical Formulae (Springer Verlag, 1974).

[13] I. L. Andronov, V. V. Breus, S. Zoła, Odessa Astron. Publ. 25, 150 (2012).

[14] Yonggi Kim, I. L. Andronov, Young-Beom Jeon, J. As- tron. Space Sci. 21, 191 (2004).

[15] V. V. Breus et al., arXiv1212.6712B (2012).

[16] I. L. Andronov, V. V. Breus, Astrophysics 56, 569 (2013); arXiv1308.1805A (2013).

[17] V. V. Breus, I. L. Andronov, T. Hegedus, P. A. Dubovsky, I. Kudzej, Adv. Astron. Space Phys. 2, 9 (2012).

[18] B. Warner, Cataclysmic Variable Stars (Cambridge University Press, 2003).

[19] C. Hellier, Cataclysmic Variable Stars (Springer, 2001).

[20] A. Bianchini, Mem. Soc. Astron. Ital. 58, 245 (1987).

[21] I. L. Andronov, L. I. Shakun, Astrophys. Space Sci. 169, 237 (1990).

[22] I. L. Andronov, Astron. Soc. Pacific Conf. Ser. 334, 447 (2005).

[23] I. L. Andronov, L. L. Chinarova, Astron. Soc. Pacific Conf. Ser. 261, 47 (2002).

[24] V. P. Tsesevich, Eclipsing Variable Stars (J. Wiley, New York, 1973).

[25] G. Tovmassian et al., Publ. Astron. Soc. Pacif. 115, 725 (2003).

[26] G. H. Tovmassian, S. V. Zharikov, V. V. Neustroev, Astron. Soc. Pacific Conf. Ser. 372, 541 (2007).

[27] I. B. Vavilova et al., Kinem. Phys. Celest. Bodies 28, 85 (2012).

[28] I. L. Andronov et al., Odessa Astron. Publ. 23, 8 (2010). 


\section{ЗМІННІСТЬ ПЕРІОДУ ОБЕРТАННЯ БІЛОГО КАРЛИКА У ПРОМІЖНОМУ ПОЛЯРI V405 AUR: ТРЕТЕ ТІЛО МАЛОЇ МАСИ ЧИ ПРЕЦЕСІЯ?}

В. В. Бреус ${ }^{1}$, І. Л. Андронов ${ }^{1}$, П. Дубовскі ${ }^{2}$, С. В. Колесніков ${ }^{3}$, Е. О. Жужуліна ${ }^{4}$, Т. Хегедиш ${ }^{5}$, П. Берінгер ${ }^{5}$, К. Петрік ${ }^{6}$, Дж. У. Робертсон ${ }^{7}$, А. В. Рябов ${ }^{3}$, І. Кудзей ${ }^{2}$, М. М. Шаховськой $^{8}$

${ }^{1}$ Кафедра "Вища та прикладна математика", Одесъкий націоналъний морсъкий університет, Oдеса, Україна, е-таil: vitaly.breus@gmail.com,tt_ari@ukr.net

${ }^{2}$ Вігорлатсъка астрономічна обсерваторія, Гуменне, Словаччина ${ }^{3}$ Астрономічна обсерваторія, Одесъкий націоналъний університет, Одеса, Украӥна

${ }^{4}$ Кафедра астрономії, Одесъкий національний університет, Одеса, Україна

${ }^{5}$ Астрономічна обсерваторія, Байя, Угорщина

${ }^{6}$ Астрономічна обсерваторія, Глоговець, Словаччина

${ }^{7}$ Арканзасъкий технічний університет, Руселвіль, США

${ }^{8}$ Кримсъка астрофізична обсерваторія, Научне, Україна

Ми представляємо результати фотометричних CCD-спостережень магнітної катаклізмічної змінної V405 Візничого (RX J0558.0+5353 = 1RXS J055800.7+535358), отримані з використанням різних інструментів. Проаналізовано змінність періоду обертання білого карлика в системі V405 Aur (RX J0558.0+5353) 3 використанням наших спостережень і раніше опублікованих моментів максимумів. Період обертання системи у 2010-2012 роках становив $P=545.4558163(94)$ сек. Оскільки в нас є прогалини в даних спостережень, ми представляємо 2 гіпотези змінності періоду обертання цієї системи - кубічну ефемериду, що може бути інтерпретована прецесією магнітного білого карлика, або періодичну змінність із періодом 6.2 року й напівамплітудою $17.2 \pm 1.8$ сек. Періодичні зміни можна інтерпретувати ефектом затримки часу на рух світла, що викликаний зорею малої маси $\left(M_{3} \geq 0.09 M_{\odot}\right)$. У цьому випадку система належить до рідкісного класу катаклізмічних змінних із третім тілом. 